\title{
Tumor Cell-selective Synergism of TRAIL- and ATRA-induced Cytotoxicity in Breast Cancer Cells
}

\author{
ANNEKATHRIN REINHARDT ${ }^{1 *}$, HONGYU LIU $^{2 *}$, YUNXIA MA $^{3}$, YONGAN ZHOU ${ }^{4}$, \\ CHUANBING ZANG ${ }^{2}$, JAN-PIET HABBEL ${ }^{2,5}$, KURT POSSINGER ${ }^{5}$ and JAN EUCKER ${ }^{2}$ \\ ${ }^{1}$ Department of Neuropathology, Institute for Pathology, University of Heidelberg, Heidelberg, Germany; \\ ${ }^{2}$ Department of Hematology and Oncology, Benjamin Franklin Campus, and \\ ${ }^{5}$ Department of Hematology and Oncology, Campus Mitte, Charité University of Medicine Berlin, Berlin, Germany; \\ ${ }^{3}$ Central Research Laboratory, Taiyuan Central Hospital, Taiyuan, P.R. China; \\ ${ }^{4}$ Second Affiliated Hospital of Shanxi Medical University, Taiyuan, P.R. China
}

\begin{abstract}
Background/Aim: One of the major problems in breast cancer treatment is pharmacoresistance. Therefore, exploration of treatment alternatives is of clinical relevance. The present work focused on tumor cell-inhibiting effects of a combination of tumor necrosis factor-related apoptosisinducing ligand (TRAIL) and all trans retinoic acid (ATRA) in breast cancer cells. Materials and Methods: Breast cancer cell lines (BT-20, BT-474, MDA-MB-231, MDA-MB-436, MDA-MB-453, MCF-7, SKBR3, T47D, ZR-75-1) and the mammary epithelial cell line MCF-10A were treated with TRAIL and ATRA alone and in combination. Cell viability was assessed via 3-(4,5)-dimethylthiahiazo(-z-yl)-3,5-diphenytetrazoliumromide (MTT) assay, the potential of cell colony formation via clonogenic assay, cell death induction via cell-cycle analysis by fluorescence-activated cell sorting (FACS), terminal deoxynucleotidyltransferase-mediated UTP nick end labeling (TUNEL) assay and Cell death detection ELISA ${ }^{\text {PLUS }}$, expression of apoptosis and TRAIL pathway proteins via western blot and cell surface expression of TRAIL receptor 1 (DR4) via FACS analysis. Results: TRAIL and ATRA evoked synergistic inhibition of breast cancer cell viability based on cytostatic and cytotoxic mechanisms. This correlated with augmented fragmentation of nuclear DNA, up-regulation of TRAIL receptor, down-regulation of cyclin D1 and enhancement of caspase activity. MCF-10A cells
\end{abstract}

This article is freely accessible online.

*These Authors contributed equally to this study.

Correspondence to: PD Dr. Jan Eucker, Charité Campus Benjamin Franklin, Hindenburgdamm 30, 12200 Berlin, Germany. Tel: +49 30450513534, Fax:+49 30450513950, e-mail: jan.eucker@charite.de

Key Words: TRAIL, retinoids, ATRA, breast cancer, apoptosis, cell death, synergism. were merely slightly susceptible to TRAIL and ATRA. Conclusion: The cytostatic and cytotoxic effects of the combination of TRAIL and ATRA are tumor cell-selective.

Resistance to cytostatic or targeted therapies is a frequently encountered issue in breast cancer (1-3). For instance, tumor progression due to resistance is the main cause of fatal outcome in metastatic breast cancer. Hence, exploration of alternative treatment algorithms is of eminent clinical relevance (1).

Tumor necrosis factor-related apoptosis-inducing ligand (TRAIL) is known to induce apoptosis of tumor cells selectively, whereas its cytotoxicity toward non-transformed cells is low to moderate. The potential of TRAIL as an anticancer agent has, therefore, been clinically tested (2-4). TRAIL ligates death domain-containing cell surface receptors called TRAIL receptor 1 (death receptor 4/DR4) and TRAIL receptor 2 (death receptor 5/DR5) (3). Despite promising results showing that TRAIL induced apoptosis of tumor cells, about $50 \%$ of tumor cell cultures displayed resistance to TRAIL-mediated cell death $(3,4)$. Interestingly, up-regulation of DR4, DR5 and pro-apoptotic B-cell lymphoma 2 (BCL2) family proteins, as well as down-regulation of anti-apoptotic BCL2 family proteins and inhibitors of apoptosis in TRAILresistant tumor cell lines correlated with sensitization to TRAIL-induced apoptosis (3-6).

The term retinoids comprises polyisoprenoids of the vitamin A group. The derivative all trans retinoic acid (ATRA) acts as an activator of transcription and thereby regulates proliferation, differentiation and apoptosis (7-10). Furthermore, retinoids have proven potential in the secondary prevention of breast cancer and in the treatment of acute promyelocytic leukemia (11-14). Retinoids exert their functions mainly through ligation of nuclear receptors known as retinoic acid receptors (RARs) and retinoid $\mathrm{X}$ receptors (RXRs). Retinoid receptors reside at so-called retinoic acid response elements (RARE) present in regulatory 
regions of retinoid target genes $(10,12,15)$. One mechanism by which retinoids display their anticancer effects is through regulation of gene products involved in apoptosis induction $(8,16-21)$. For instance, retinoids modulate components of the TRAIL signal transduction pathway and therefore sensitize tumor cell lines to TRAIL-induced apoptosis through up-regulation of DR4 and DR5, augmentation of caspase activity, augmentation of BCL2-associated X protein (BAX) translocation to the mitochondrial membrane, cytochrome $c$ release, as well as down-regulation of BCL2 and B-cell lymphoma-extra large (BCL-xl) (18, 20-25). Given this apparent convergence of TRAIL and retinoid signaling pathways at the level of TRAIL receptors, BCL2 family proteins and caspases, we assumed a mutual augmentation of TRAIL- and retinoid-induced cytotoxicity.

This study aimed to explore and characterize tumor cellinhibiting effects of a combination of TRAIL and ATRA in in vitro breast cancer models.

\section{Materials and Methods}

Substances. ATRA was purchased from Sigma-Aldrich (Munich, Germany) and dissolved in ethanol at a concentration of $10 \mu \mathrm{M}$. Recombinant human TRAIL (R\&D Systems, Minneapolis, MN, USA) was dissolved in sterile phosphate-buffered saline (PBS) at a concentration of $50 \mu \mathrm{g} / \mathrm{ml}$. All stock solutions were stored at $-80^{\circ} \mathrm{C}$ and then further diluted to appropriate concentrations with medium before use.

Cell lines and cell culture. Human breast cancer cell lines BT-20, BT-474, MDA-MB-231, MDA-MB-436, MDA-MB-453, MCF-7, SKBR3, T47D, ZR-75-1 and the human mammary gland cell line MCF-10A were purchased from the American Type Culture Collection (Rockville, MD, USA). Cell lines were maintained in RPMI-1640 medium supplemented with $10 \%$ fetal bovine serum (FBS) and $1 \%$ penicillin/streptomycin (P/S). SKBR3 cell line was cultured in McCoy's 5A medium with 10\% FBS and 1\% P/S. MCF$10 \mathrm{~A}$ cells were cultured in mammary epithelial cell growth medium (MEGM) with $20 \% \mathrm{FBS}, 4 \mathrm{mmol} / \mathrm{l}$ glutamine, $52 \mu \mathrm{g} / \mathrm{ml}$ bovine pituitary extract, $0.5 \mu \mathrm{g} / \mathrm{ml}$ hydrocortisone, $10 \mathrm{ng} / \mathrm{ml}$ human epidermal growth factor, $5 \mu \mathrm{g} / \mathrm{ml}$ insulin and gentamycin/ amphotericin B 1000 Mix. All cell lines were grown in a humid atmosphere at $37^{\circ} \mathrm{C}$ with $5 \% \mathrm{CO}_{2}$. The cell lines used for this study as well as their respective receptor status are listed in Table I.

3-(4,5)-Dimethylthiazo(-z-yl)-3,5-diphenytetrazolium bromide (MTT) cell viability assay. MTT assay was used to measure cell proliferation as previously described (26). Breast cancer cells were seeded into a 96 -well plate at a density of $4 \times 10^{4}$ to $8 \times 10^{4}$ cells per well. After an adhesion period of $24 \mathrm{~h}$, cells were washed with PBS, the medium was changed and cells were exposed to TRAIL (2.5-80 $\mathrm{ng} / \mathrm{ml})$, ATRA $(0.025-1.6 \mu \mathrm{mol} / \mathrm{l})$ or the combination of TRAIL and ATRA (in the same concentration ranges) in culture medium. After incubation for 4-5 days, MTT reagent (Sigma-Aldrich, St. Louis, MO, USA) was added to each well and cells were incubated for another $4 \mathrm{~h}$. The reaction was stopped with $0.01 \mathrm{~N}$ hydrochloric acid in $10 \%$ sodium dodecyl sulfate solution overnight and the absorbance was measured at $512 \mathrm{~nm}$ on an ELISA reader (anthos ht2; Anthos Microsystems, Friesoythe, Germany). Cell viability of the treated cell cultures was assessed as percentage of the untreated control cell culture.

Clonogenic assay in suspension culture. The effect of ATRA in combination with TRAIL on clonogenic growth of breast cancer cells was determined by clonogenic assay in suspension culture. MCF-7, ZR-75-1 and SKBR3 cells were grown in culture medium in 24-well plates at an initial density of 400-7,000 cells per well without growth factors. TRAIL $(2.5,5.0$ or $20.0 \mathrm{ng} / \mathrm{ml})$, ATRA (7.5, 10.0 or $25.0 \mu \mathrm{mol} / \mathrm{l}$ ) or their combination (at equal concentrations) were added after a 24 -h period of adherence and medium change. After incubation for 7 (MCF-7) or 14 (SKBR3, ZR-75-1) days, cell colonies were visualized by Quick stain (Merck, Darmstadt, Germany) and photographed. During the 14-day incubation period, medium change and addition of TRAIL, ATRA or their combination at the same concentrations as before was carried out after 7 days.

Cell cycle analysis. For cell death analysis, treated cells were harvested and fixed in $70 \%$ ethanol at $4^{\circ} \mathrm{C}$ for $30 \mathrm{~min}$. Cells were washed twice with PBS and stained with propidium iodide $(0.1 \mathrm{mg} / \mathrm{ml})$ for $2 \mathrm{~h}$ at $37^{\circ} \mathrm{C}$. Cell death analysis was performed on a FACSCalibur flow cytometer (Becton Dickinson, Franklin Lakes, NJ, USA) as described previously (26). Cell death was defined as the proportion of cells in the sub- $\mathrm{G}_{1}$ phase of the cell cycle.

Terminal deoxynucleotidyltransferase-mediated UTP nick-end labeling (TUNEL) assay. Cell cultures were seeded in 12-well plates at a density of $3.5 \times 10^{5}$ cells per well. After an adhesion period of $24 \mathrm{~h}$, cells were washed with PBS, the medium was changed and cells were exposed to TRAIL ( $40 \mathrm{ng} / \mathrm{ml})$, ATRA $(0.4 \mu \mathrm{mol} / \mathrm{l})$ or the combination of TRAIL and ATRA (at the same concentrations) in culture medium. After incubation for another $24 \mathrm{~h}$, cells were harvested and aliquots of 6,000 cells in $200 \mu \mathrm{l}$ medium were established. A standardized volume was then cytospun onto glass slides. The air-dried slides were then incubated in fresh fixation reagent for $1 \mathrm{~h}$, washed with PBS and incubated in a humid chamber on ice. After a treatment with ice-cold permeabilization reagent, slides were again washed with PBS twice. DNA strand breaks in apoptotic cells were identified by TUNEL technique using an in situ Cell Death Detection Kit (Roche, Basel, Switzerland) following the instructions of the manufacturer. Evaluation of DNA fragmentation was carried out using a fluorescence light microscope with a detection wavelength of 515 to $565 \mathrm{~nm}$.

Cell death detection ELISAPLUS. Cell cultures were seeded in 96well plates at a density of 5000 cells per well. After an adhesion period of $24 \mathrm{~h}$, cells were washed with PBS, medium was changed and cells were exposed to TRAIL $(5 \mathrm{ng} / \mathrm{ml})$, ATRA $(0.05 \mu \mathrm{mol} / \mathrm{l})$ or the combination of TRAIL and ATRA (at the same concentrations) in culture medium. After incubation for another 5 days, plates were centrifuged, the medium was removed and apoptotic cell death was determined using cell death detection ELISAPLUS kit (Roche) according to the manufacturer's recommendations with modifications (27). Briefly, after lysis and centrifugation, cell lysates were incubated with biotin-labelled anti-histone and with peroxidase-labelled antibodies to DNA in a streptavidin-coated microtiter plate for $2 \mathrm{~h}$ at room temperature. After incubation, peroxidase substrate was added, the plate was incubated at room 
Table I. Characteristics of cell lines used in this study. Data were obtained from the respective ATCC (American Type Culture Collection) data sheets and from (5, 6, 39, 62-6861-67).

\begin{tabular}{|c|c|c|c|c|c|c|c|c|c|c|c|}
\hline \multirow[t]{2}{*}{ Cell type } & \multirow[t]{2}{*}{ Cellline } & \multirow[t]{2}{*}{ Morphology } & \multicolumn{3}{|c|}{$D R$} & \multicolumn{2}{|c|}{$R A R$} & \multicolumn{3}{|c|}{$R X R$} & \multirow{2}{*}{$\begin{array}{l}\text { Tissue-specific } \\
\text { characteristics }\end{array}$} \\
\hline & & & 4 & 5 & $\alpha$ & $\beta$ & $\gamma$ & $\alpha$ & $\beta$ & $\gamma$ & \\
\hline \multirow{9}{*}{ Breast cancer } & MCF-7 & $\mathrm{Ep} / \mathrm{Lu}$ & ++ & + & ++ & 0 & + & ++ & + & 0 & ER+, HER $2 /$ neu$^{*}$ \\
\hline & $\mathrm{T} 47 \mathrm{D}$ & $\mathrm{Ep} / \mathrm{Lu}$ & + & + & ++ & 0 & + & + & + & 0 & ER+, HER $2 /$ neu$^{*}$ \\
\hline & ZR-75-1 & $\mathrm{Ep} / \mathrm{Lu}$ & + & + & ++ & + & & + & & & ER+, HER2/neu* \\
\hline & SKBR3 & $\mathrm{Ep} / \mathrm{Lu}$ & + & + & ++ & 0 & + & + & & & ER-, HER $2 /$ neu $\uparrow$ \\
\hline & BT-474 & $\mathrm{Ep} / \mathrm{Lu}$ & + & + & + & 0 & + & & & & ER,+ HER $2 /$ neu $\uparrow$ \\
\hline & BT-20 & $\mathrm{Ep} / \mathrm{Ba}$ & + & 0 & + & 0 & + & + & + & 0 & ER-, HER 2/neu* \\
\hline & MDA-MB-231 & Mes & ++ & ++ & 0 & + & + & + & & & ER-, HER 2/neu* \\
\hline & MDA-MB-436 & Mes & + & + & & & & & & & ER-, HER2/neu* \\
\hline & MDA-MB-453 & $\mathrm{Ep} / \mathrm{Lu}$ & - & + & & & & & & & ER-, HER $2 /$ neu $\uparrow$ \\
\hline Mammary gland & MCF-10A & $\mathrm{Ep} / \mathrm{Ba}$ & + & + & + & & & + & & & ER-, HER $2 /$ neu- \\
\hline
\end{tabular}

Ep: Epithelial, Lu: luminal, Ba: basal, Mes: mesenchymal, ER: estrogen receptor, PR: progesterone receptor, HER2/neu: human epidermal growth factor receptor $2,+$ expressed, ++ highly expressed, - not expressed, $\bigcirc$ beneath detection threshold, *moderately expressed, $\uparrow$ highly expressed due to gene amplification.

temperature for about $10 \mathrm{~min}$ and the peroxidase activity was determined by anthos ht2 ELISA reader at a detection wavelength of $405 \mathrm{~nm}$. Data are presented as fold increase of optical density compared to the untreated control.

Western blot. Breast cancer cells were seeded in petri dishes of $10 \mathrm{~cm}$ diameter and grown to $85 \%$ confluence. The medium was then changed and cells were treated with TRAIL $(2.5-10.0 \mathrm{ng} / \mathrm{ml})$, ATRA (0.025-0.5 $\mu \mathrm{mol} / \mathrm{l})$ and their combination (at the same concentration ranges) for 5 days. After incubation, cells were harvested and incubated in 90\% Phosphosafe Lysis Buffer (Novagen, Darmstadt, Germany) and 10\% Complete Protease Inhibitor (Roche) Protein concentrations of cell lysates were assessed using the BCA protein assay kit (Thermo Fisher Scientific, Waltham, MA, USA). The following antibodies were purchased from Santa Cruz (Heidelberg, Germany): myeloid cell leukemia 1 (MCL1), BCL2, BCL2 homologous antagonist/killer (BAK), survivin, cyclin D1, DR5, and $\beta$-actin. The following antibodies were bought from Cell Signaling (Danvers, MA, USA): truncated BH3-interacting domain death agonist (t-BID), poly ADP-ribose polymerase 1 (PARP) and caspase3. Horseradish peroxidase-labeled anti-mouse $\mathrm{IgG}$, anti-rabbit IgG and anti-goat $\operatorname{IgG}$ from Santa Cruz were used as secondary antibodies. Primary antibodies were diluted from 1:200 to 1:5,000. Western blot analysis was performed as described previously (26).

Determination of cell surface DR4 expression by flow cytometry. After incubation with TRAIL ( 25 and $50 \mathrm{ng} / \mathrm{ml})$, ATRA $(1 \mu \mathrm{mol} / \mathrm{l})$ or the combination of TRAIL and ATRA (at the same concentrations), breast cancer cells were trypsinized, washed once with PBS with $1 \%$ bovine serum albumin and $25 \mathrm{mM}$ EDTA. Cells were then resuspended in $100 \mu \mathrm{l}$ PBS, incubated with $20 \mu \mathrm{l}$ of phycoerythrinconjugated DR4 antibody or isotype control antibody (eBioscience, Affymetrix, Santa Clara, CA, USA) on ice for 25-30 min. The cells were washed again with cold PBS, suspended, filtered through FACS filter tubes before analysis and measured with a FACSCalibur flow cytometer (Becton Dickinson, Franklin Lakes, NJ, USA).
Statistical analysis. All numerical data are reported as average values \pm standard deviation. All data represent the results of at least three independent experiments. Groups of data were compared by means of Student's $t$-test ( $p$-values were adjusted for multiple testing). Synergistic and additive effects on cell proliferation resulting from the combination of TRAIL and ATRA were assessed according to the Chou and Talalay principle of dose-effect relationship (28) and analyzed by means of Calcusyn software (Biosoft, Great Shelford, Cambridge, UK). Briefly, the dose-effect curve for each agent alone was determined based on the experimental observations of MTT assay using the median effect principle. The combination index (CI) for each experimental combination was then calculated according to the following equation:

$$
\mathrm{CI}=\frac{(D)_{1}}{\left(D_{x}\right)_{1}}+\frac{(D)_{2}}{\left(D_{x}\right)_{2}}+\frac{(D)_{1}(D)_{2}}{\left(D_{x}\right)_{1}\left(D_{x}\right)_{2}}
$$

here (D) $)_{1}$ and (D) $)_{2}$ represent the doses of drug 1 and drug 2 that have $\mathrm{x}$ effect when used in combination. $\left(\mathrm{D}_{\mathrm{x}}\right)_{1}$ and $\left(\mathrm{D}_{\mathrm{x}}\right)_{2}$ were the doses of drug 1 and drug 2 when used alone. A value of CI of 1 indicates additive effects; $\mathrm{CI}<1$ indicates an effect greater than (synergism) and $\mathrm{CI}>1$ less than (antagonism) the expected additive effect.

\section{Results}

TRAIL and ATRA sensitivity is cell type-dependent. As a basis for the exploration of combination effects, breast cancer cell lines of different morphologies ranging from mesenchymallike to epithelial-like phenotypes, as well as nonmalignant mammary epithelial cells, were examined for their sensitivity to TRAIL and ATRA as single agents. In accordance with the results reported by Rahman et al. (5), cell proliferation experiments by the MTT assay showed that triple-negative 


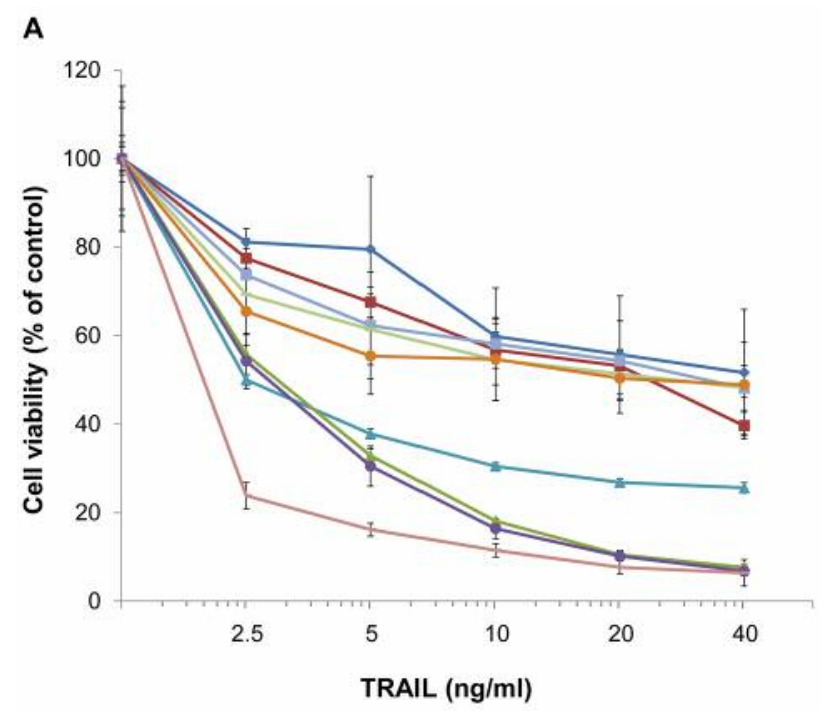

Table II. IC 50 values for TRAIL and ATRA alone and in combination in breast cancer cell lines. For each substance combination, the combination index $(\mathrm{CI})$ is also listed. Cell lines were incubated with increasing concentrations of TRAIL, ATRA or their combination. Dependent on the cell line, maximum concentrations for TRAIL were 20-80 $\mathrm{ng} / \mathrm{ml}$ and for ATRA 100-1,000 nmol/l. IC 50 and CI values were calculated from the MTT data via CalcuSyn software. $I C_{50}$ : inhibitory concentration 50, TRAIL: tumor necrosis factor-related apoptosisinducing ligand, ATRA: trans retinoic acid.

\begin{tabular}{lcccc}
\hline & \multicolumn{3}{c}{$\mathrm{IC}_{50}$} & \\
\cline { 2 - 4 } & $\begin{array}{c}\text { TRAIL } \\
(\mathrm{ng} / \mathrm{ml})\end{array}$ & $\begin{array}{c}\text { ATRA } \\
(\mathrm{nM})\end{array}$ & $\begin{array}{c}\text { TRAIL }(\mathrm{ng} / \mathrm{ml})+ \\
\text { ATRA (nM) }\end{array}$ & CI \\
\hline MCF-7 & 3187 & $6 \times 10^{12}$ & $344 / 4300$ & 0.1 \\
T47D & 462 & 3847 & $27 / 135$ & 0.1 \\
SKBR3 & 28 & 454 & $2 / 20$ & 0.1 \\
BT-474 & $6 \times 10^{5}$ & $\infty$ & $290 / 19346$ & $4.7 \times 10^{-4}$ \\
MB-453 & 32 & 4272 & $118 / 2352$ & 4.3 \\
\hline
\end{tabular}

B

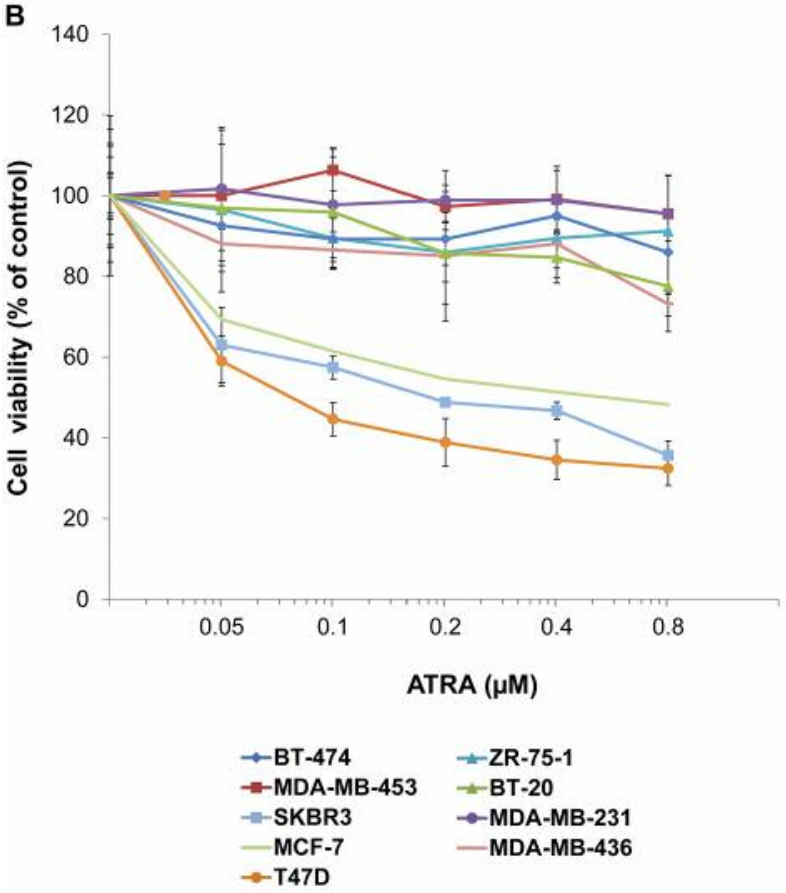

Figure 1. Breast cancer cell lines have different sensitivities to ATRA and TRAIL treatment. A: The indicated cell lines were treated with 2.5 , 5, 10, 20, $40 \mathrm{ng} / \mathrm{ml}$ TRAIL in 96-well plates. After $96 \mathrm{~h}$, cell viabilities were assessed by MTT assay. Data are means $\pm S D$ s of triplicate determinations. B: The indicated cell lines were treated with $0.05,0.1$, 0.2, 0.4, $0.8 \mathrm{\mu mol} / \mathrm{l}$ ATRA in 96-well plates. After $96 \mathrm{~h}$, cell viabilities were assessed by MTT assay. Data are means $\pm S D$ s of triplicate determinations. TRAIL: tumor necrosis factor-related apoptosisinducing ligand, ATRA: trans retinoic acid.

breast cancer cell lines with a mesenchymal phenotype such as MDA-MB-436 and MDA-MB-231 were particularly highly sensitive to TRAIL, whereas the triple-negative, but epithelial cell line BT-20, as well as estrogen receptor (ER) $\alpha$ -

expressing epithelial MCF-7, T47D and ZR-75-1 cell lines were highly resistant. The epithelial but human epidermal growth factor receptor 2 (HER2) -amplified cell lines showed different susceptibilities: whereas BT-474 was as resistant as the ER $\alpha$-positive epithelial cell lines, SKBR3 was slightly to moderately sensitive (Figure 1A).

Correlations between breast cancer phenotype and retinoid susceptibility showed a partially inverse pattern: triple-negative and mesenchymal cell lines MDA-MB-436 and MDA-MB-231 with high TRAIL sensitivity were highly resistant towards retinoids, whereas the TRAIL-resistant ER $\alpha$-expressing epithelial T47D and ZR-75-1 cells displayed relatively high response to retinoid (Figure 1B). However, MCF-7 was resistant. From the HER2-overexpressing epithelial cell lines investigated, BT-474 was also resistant to and SKBR3 was susceptible to retinoids. Interestingly, nonmalignant MCF-10A epithelial cells derived from the mammary gland were resistant to TRAIL as well as to retinoids.

In summary, breast cancer cell lines were categorized as follows: a TRAIL-sensitive and retinoid-resistant subgroup, comprising triple-negative cell lines of mesenchymal phenotypes such as MDA-MB-436 and MDA-MB-231; a TRAIL-resistant and retinoid-sensitive subgroup, comprising the ER $\alpha$-expressing cell lines of epithelial phenotypes T47D and ZR-75-1. SKBR3 may be classified as moderately sensitive towards both agents. In addition, the category of cell lines resistant towards both agents consisted of BT-474 and the nonmalignant mammary epithelial cell line MCF-10A.

Cell type-specific synergism of TRAIL and ATRA combination on inhibition of proliferation. In order to identify a possible combinatory effect of TRAIL and ATRA 
A
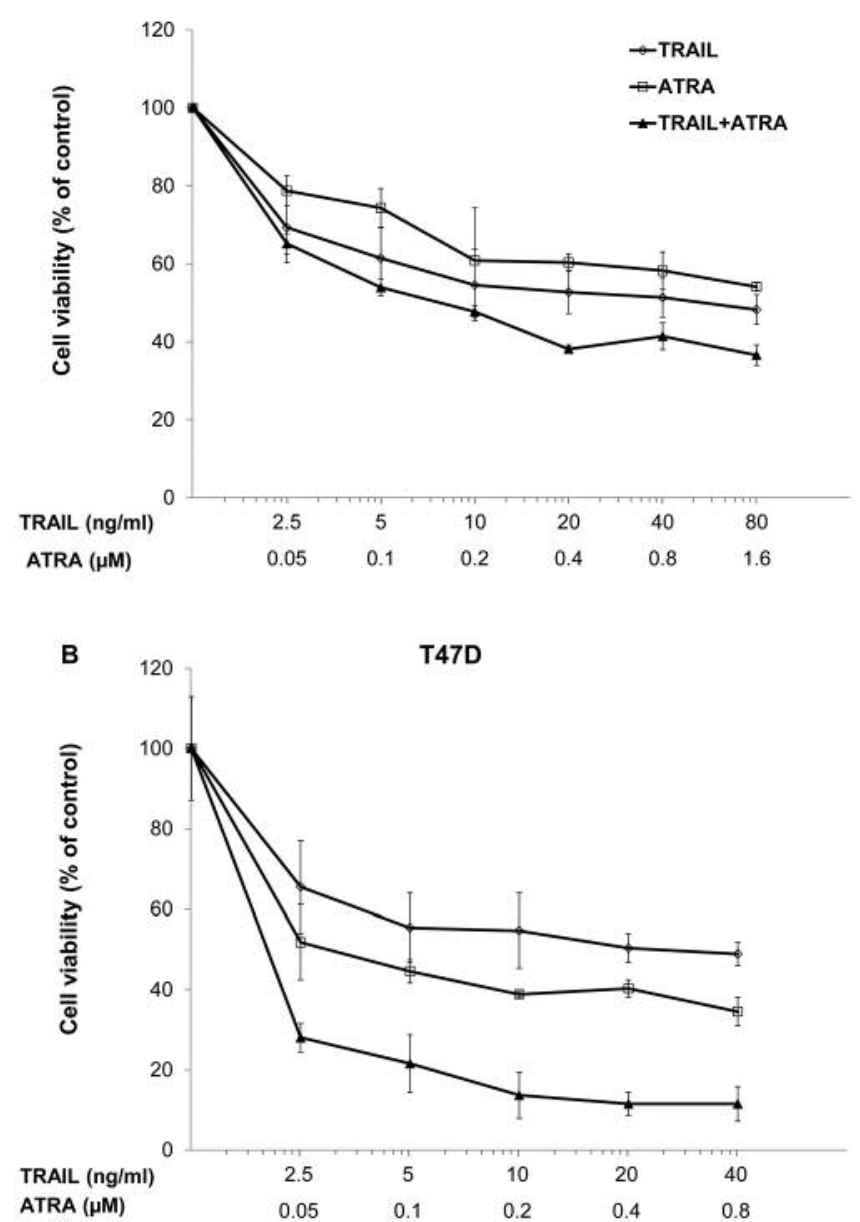

C

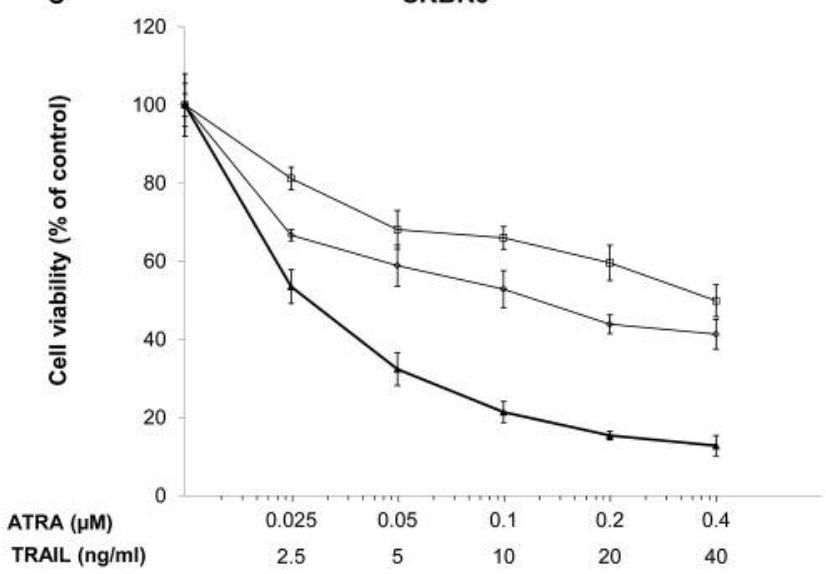

on cell viability, MTT assay was performed. Firstly, the $50 \%$ inhibitory concentration $\left(\mathrm{IC}_{50}\right)$ values for the single agents were determined for each cell line. Based on cell linespecific $\mathrm{IC}_{50}$ values, individual dilution series of
D

BT-474

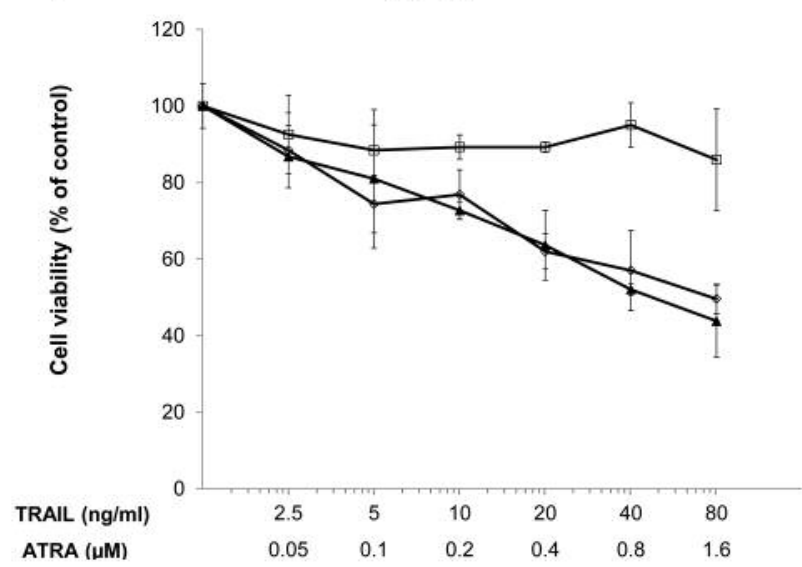

E

MDA-MB-453

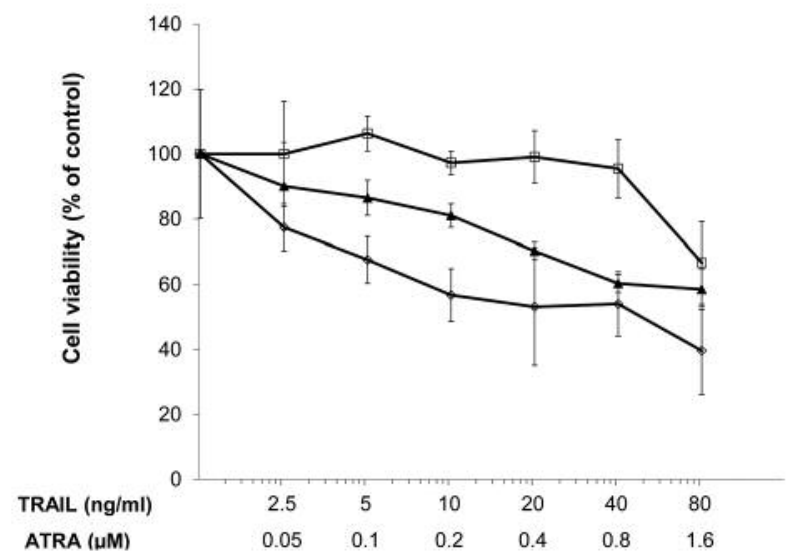

Figure 2. The combination of TRAIL and ATRA displays synergistic effects in reducing breast cancer cell viability. The indicated cell lines were treated with TRAIL alone, ATRA alone and their respective combinations in 96-well plates. After $96 \mathrm{~h}$, cell viability was assessed by MTT assay. Data are means $\pm S D$ s of six single determinations, respectively. TRAIL: tumor necrosis factor-related apoptosis-inducing ligand, ATRA: trans retinoic acid.

exponentially increasing concentrations were established for the combination regimen. Figure 2 shows the dose-dependent reduction of cell viability in MCF-7, T47D, SKBR3, BT-474 and MDA-MB-453 breast cancer cells for TRAIL, ATRA 
and their combination. In MCF-7, T47D and SKBR3 cultures, inhibition of cell proliferation by the combination regimen was more than additive as confirmed by the combination index $(\mathrm{CI})$ for the respective $\mathrm{IC}_{50}$ values of around 0.1 (Table II). In fact, these results indicate that $\mathrm{IC}_{50}$ values for retinoids are eminently reduced by combination with TRAIL. Under these conditions, IC50 values for ATRA in T47D and SKBR3 cells were $3.6 \%$ and $4.3 \%$ of the values calculated for the respective mono-regimen. Conversely, it was also observed that the combination of TRAIL and ATRA reduced the $\mathrm{IC}_{50}$ values for TRAIL to $11.1 \%, 5.9 \%$ and $7.1 \%$ of the initially calculated value for TRAIL monotherapy in MCF-7, T47D and SKBR3 cultures (Table II).

The reduction in cell viability at the highest concentration of the TRAIL and ATRA combination was $37 \%$ for MCF-7, $51 \%$ for T47D and $77 \%$ for SKBR3 cells. In contrast, BT474 and MDA-MB-453 cells were not susceptible to a combination effect (Figure 2D and E). The CI for the $\mathrm{IC}_{50}$ of TRAIL and ATRA combination when applied to MDAMB-453 cells indicates antagonism. In contrast, the calculated CI for this regimen in BT-474 cells indicates synergism, but the calculated concentration particularly for ATRA at the $\mathrm{IC}_{50}$ was exceedingly high. However, in MDAMB-231 cells, which are known to be TRAIL-sensitive, no further augmentation of inhibition of proliferation was achieved by simultaneous addition of ATRA and TRAIL (data not shown). Interestingly, in MCF-10A cell cultures, a reduction in cell viability after combinational incubation with TRAIL and ATRA was not obvious even at comparatively high concentrations (respective $\mathrm{IC}_{50}$ values were not reached for TRAIL doses up to $320 \mathrm{ng} / \mu \mathrm{l}$ and for ATRA doses up to $3.2 \mu \mathrm{mol} / 1)$.

In summary, these results suggest that the combination of TRAIL and ATRA reduces cell viability in a certain subset of epithelial breast cancer cells in vitro.

TRAIL and ATRA-induced inhibition of proliferation is based on cytotoxic and cytostatic mechanisms. To explore whether the combinatory effect of TRAIL and ATRA on cell cultures as a whole is also reproducible on the single-cell level, we investigated clonal proliferation in the presence and absence of these agents by clonogenic assay. In MCF-7 and SKBR3 cells, even application of these compounds as single agents led to a reduction of the number, diameter and cell density of respective colonies, indicating both cytostatic and cytotoxic mechanisms. Moreover, the TRAIL and ATRA combination clearly augmented these inhibitory effects in comparison to single-agent treatment. In ZR-75-1 cells, similar tendencies were clear (Figure 3 ).

These data reveal that the inhibition of cell proliferation in breast cancer cultures by TRAIL, ATRA and their combination is based on both cytostatic and cytotoxic processes.
Enhancement of cell death induction by a combination of TRAIL and ATRA in breast cancer cells. TRAIL is a potential cancer therapeutic cytokine with the ability to preferentially induce apoptosis of transformed or malignant cells. However, this apoptosis-inducing effect is attenuated in some cancer cell lines upon TRAIL treatment due to intrinsic resistance. Cell-cycle analysis by flow cytometry was used to investigate whether combination with ATRA enhances apoptosis of TRAIL-treated breast cancer cells.

By determining the fraction of sub-G1 phase cells, adding ATRA to TRAIL treatment synergistically augmented apoptosis as compared to exposure to TRAIL alone in three breast cancer cell lines, MCF-7, T47D and SKBR3, for which relatively low to moderate sensitivity to TRAIL was observed. The fraction of cells in the sub-G1 phase in cultures treated with ATRA and TRAIL compared to those treated with TRAIL alone was $31.53 \%$ versus $11.83 \%$ for T47D, $46.50 \%$ versus $4.42 \%$ for MCF-7 and $74.28 \%$ versus $52.37 \%$ for SKBR3 (Figure 4A).

These results were confirmed by two further methods detecting correlates for apoptosis induction in SKBR3 cells: TUNEL assay, which assesses nuclear (in situ) DNA fragmentation and Cell Death Detection ELISA ${ }^{\text {PLUS }}$, which assesses the amount of cytoplasmic oligonucleosomes (Figure 4B and C). As indicated in Figure 4B, even application of TRAIL and ATRA as single agents resulted in augmentation of nuclear fluorescence in SKBR3 cells compared to the untreated control, indicating an increased fragmentation of nuclear DNA as a reflection of apoptosis induction. Moreover, nuclear fluorescence was further enhanced through simultaneous incubation with both agents in comparison to single agents, suggesting an increase of apoptosis induction by the combination of TRAIL and ATRA. As indicated for nuclear DNA fragmentation, TRAIL and ATRA also induced an increase of nucleosome enrichment in supernatants of SKBR3 cytoplasm, whose extent was only slight in cultures treated with single agents (Figure 4C). However, after adjustment for multiple testing, the p-values for the differences between the single-agent and the combination treatments were slightly below the accepted level of significance.

Based on the findings that the combination of TRAIL and ATRA cooperatively caused cell death in vitro, the underlying mechanisms were investigated, especially focusing on diverse components and pathways of apoptosis induction. Western blot analysis was performed on whole-cell lysates of treated and untreated SKBR3 cells (Figure 5). These analyses revealed TRAIL- and ATRA-induced augmentation of cleavage of the caspase- 3 substrate PARP, as well as a TRAIL-induced augmentation of cleaved caspase- 3 . Moreover, the combination of TRAIL and ATRA resulted in a slightly further augmentation of PARP and caspase-3 cleavage. Furthermore, ATRA induced reduction of the antiapoptotic proteins survivin and BCL2, whereas no further 


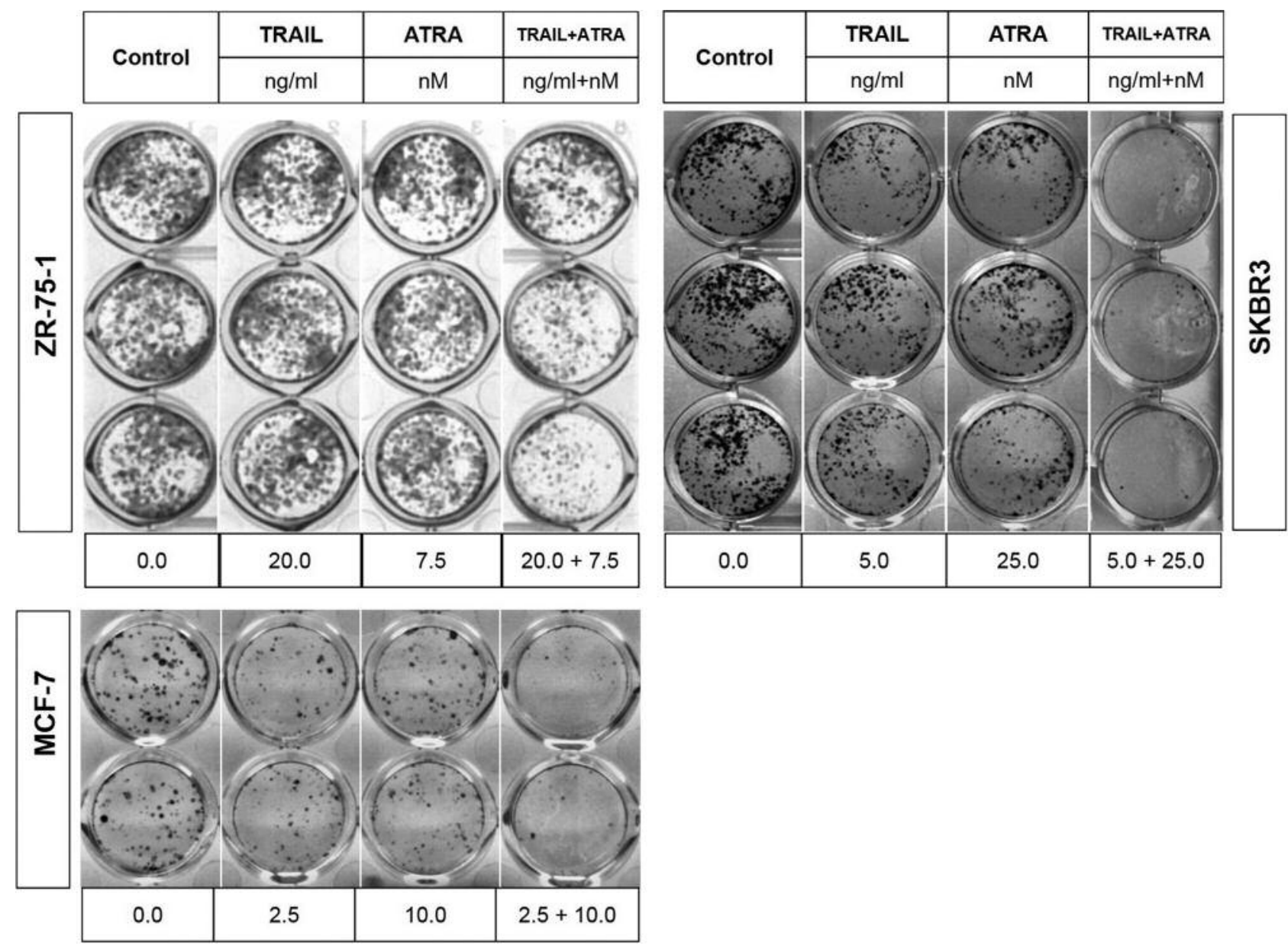

Figure 3. Colony formation of breast cancer cell lines is dependent on treatment with TRAIL, ATRA or their combination in comparison to an untreated control. ZR-75-1, SKBR3 and MCF-7 cell lines were seeded in 12-well plates, treated with the outlined concentrations of TRAIL, ATRA and their combination and fixed and visualized by Quick stain. TRAIL: tumor necrosis factor-related apoptosis-inducing ligand, ATRA: trans retinoic acid.

decrease was observed in cultures simultaneously treated with ATRA and TRAIL. TRAIL alone and in combination with ATRA induced reduction of the anti-apoptotic protein MCL1. However, there was no indication for an additive or a synergistic effect. Incubation with ATRA alone as well as in combination with TRAIL also resulted in increased amounts of the pro-apoptotic BCL2 family members t-BID and BAK. Again, no further effect was seen upon addition of ATRA. Finally, ATRA as a single-agent induced down-regulation of the proliferation-initiating cell-cycle component cyclin D1 and simultaneous incubation with TRAIL led to a further decrease in the amount of cyclin D1 protein. These results allow the suggestion that ATRA may enhance TRAIL-induced apoptosis by up-regulation of pro-apoptotic (t-BID and BAK) and down-regulation of anti-apoptotic (survivin and BCL2) TRAIL signaling pathway components. Furthermore, our data show that ATRA alone, as well as in combination with
TRAIL, exerts inhibitory effects on SKBR3 cell proliferation at least in part by down-regulating cyclin D1 and thereby decelerating cell-cycle progression.

ATRA enhances TRAIL-induced apoptosis, at least in part, through up-regulation of death receptors. In vitro studies demonstrated that retinoids enhance TRAIL-induced apoptosis in tumor cell lines of different entities such as prostate, lung, ovarian and head and neck cancer, as well as Ewing sarcoma. These investigations also revealed an association of these effects with retinoid induced upregulation of death receptors $(20,22)$. Accordingly, the effect of ATRA treatment on the amounts of apoptosis-inducing TRAIL receptors DR4 and DR5 in SKBR3 cells was determined by FACS and western blot analyses.

ATRA alone increased the proportion of DR4-positive cells significantly from $9.26 \%$ in vehicle-treated cultures to 
A
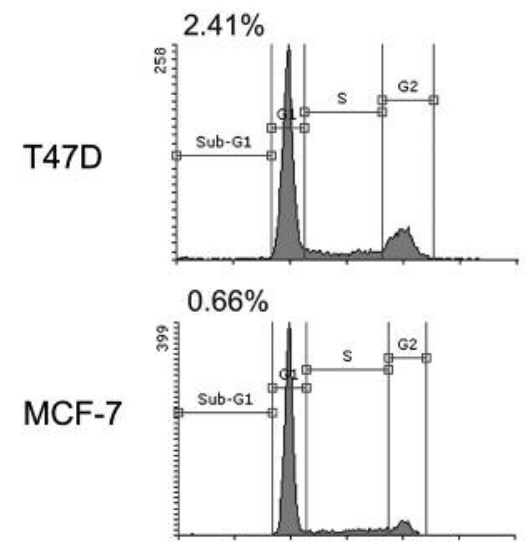

$7.25 \%$

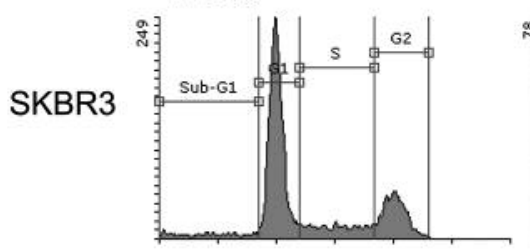

TRAIL $10 \mathrm{ng} / \mathrm{ml}$

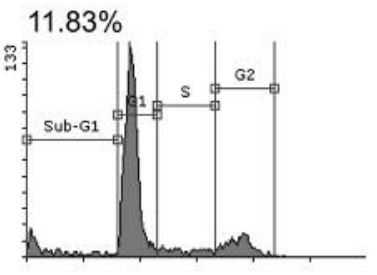

$4.42 \%$

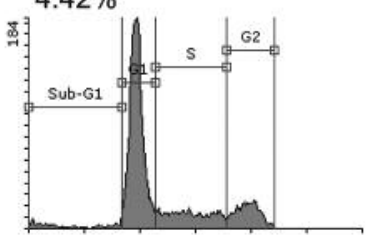

$52.37 \%$

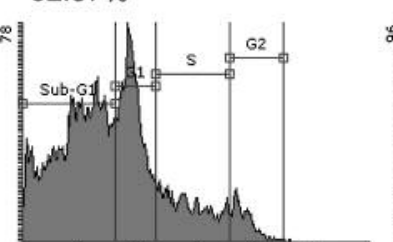

ATRA $0.5 \mu \mathrm{M}$

$11.28 \%$

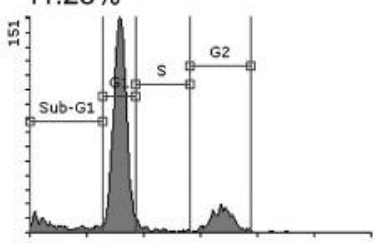

$13.33 \%$

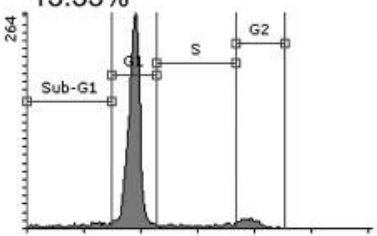

$8.14 \%$

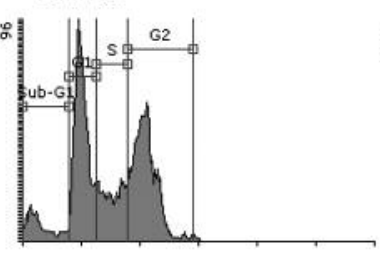

TRAIL+ATRA

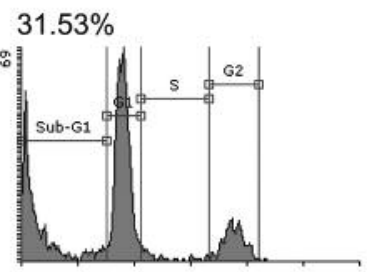

$46.50 \%$

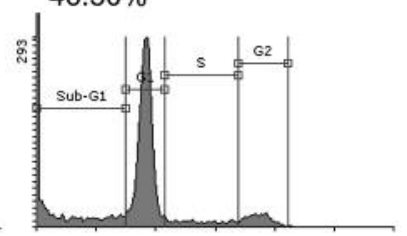

$74.28 \%$

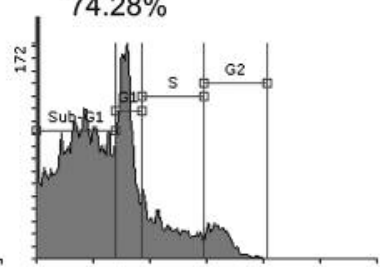

B

SKBR3
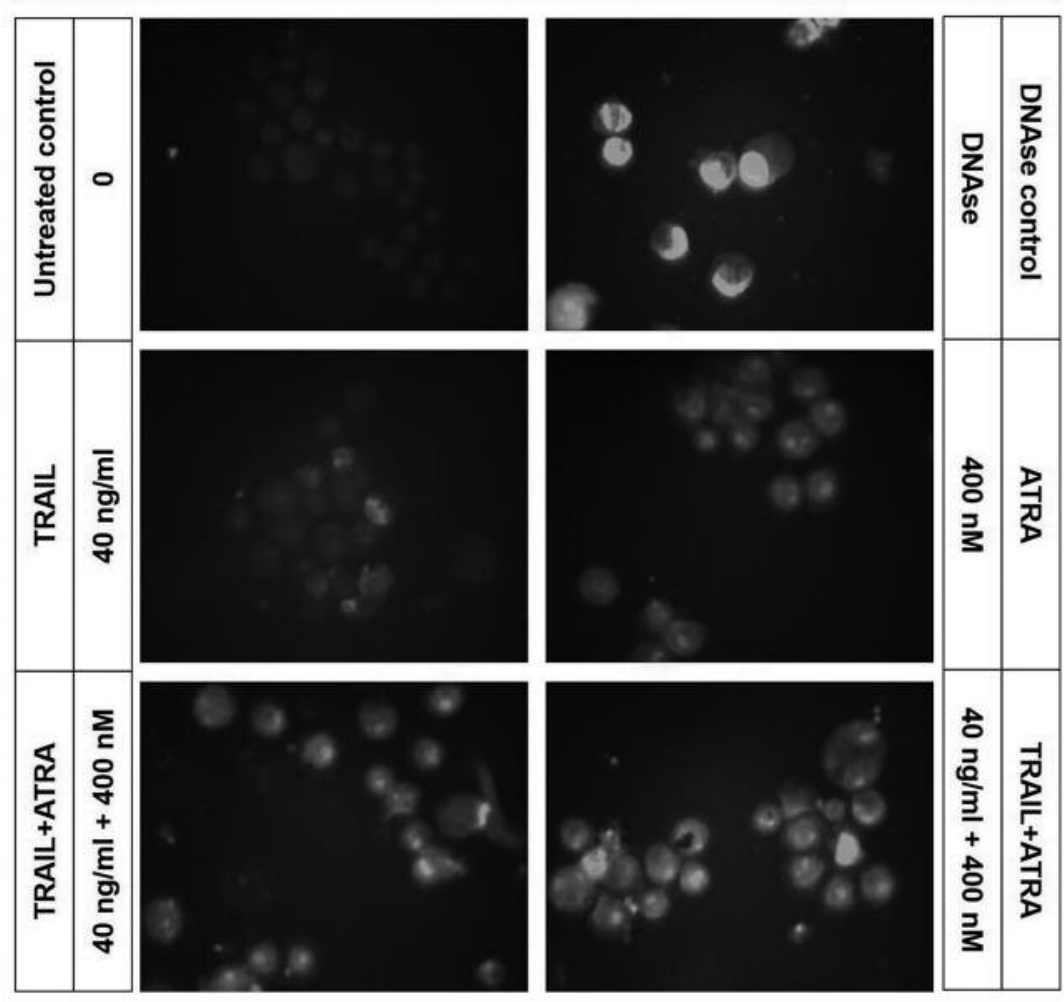

Figure 4. Continued 
c

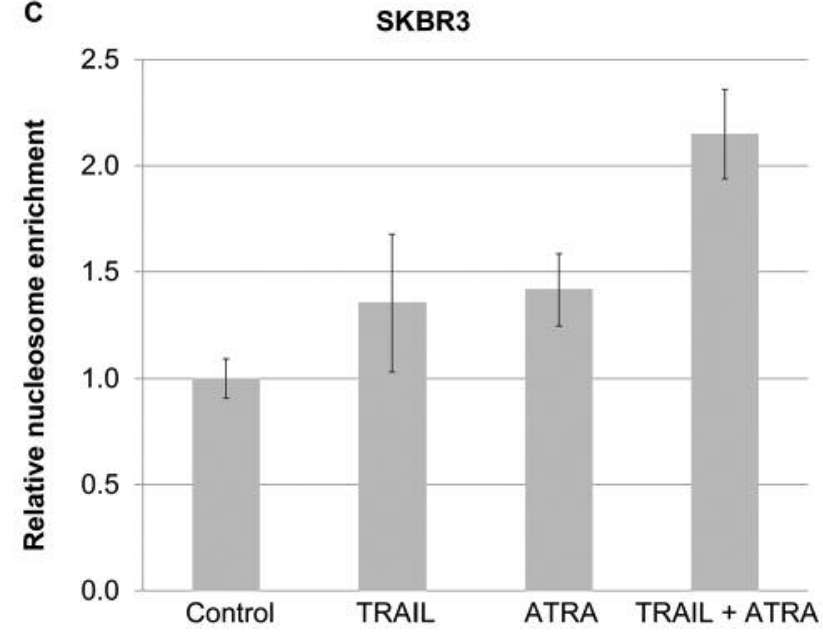

Figure 4. The combination of TRAIL and ATRA synergistically induces apoptosis in ATRA-sensitive breast cancer cell lines. A: T47D, MCF-7, and SKBR3 cells were treated with TRAIL $(10 \mathrm{ng} / \mathrm{ml})$, ATRA $0.5 \mu \mathrm{M}$ or the combination of TRAIL and ATRA, respectively, for $48 \mathrm{~h}$. Cells were fixed in $70 \%$ ethanol and stained with propidium iodide. The proportion of cells in the sub-G $G_{1}$ phase was determined by flow cytometry. The $x$ axes indicate the DNA content. The y-axes indicate the cell count. B: SKBR3 cells were seeded in 24-well plates, treated with the indicated concentrations of TRAIL, ATRA or their combination for $24 \mathrm{~h}$, then analyzed by the TUNEL assay. Untreated cells served as negative control, DNAse-treated cells as positive control. C: SKBR3 cell were seeded in 96-well plates and incubated with $5 \mathrm{ng} / \mathrm{ml}$ TRAIL, $50 \mathrm{nmol} / \mathrm{l}$ ATRA or their combination for 4 days. Quantification of cytoplasmic nucleosomes was carried out by Cell Death Detection ELISAPLUS. Nucleosome enrichment values were normalized to the control and to the average cell count in the respective probes. TRAIL vs. TRAIL +ATRA, $p=0.0258$; ATRA vs. TRAIL+ATRA, $p=0.0271$. Level of significance (adjusted to multiple testing): $\alpha / 2=0.0250$. TRAIL: tumor necrosis factor-related apoptosis-inducing ligand, ATRA: trans retinoic acid.

$12.68 \%$ in ATRA-treated cultures, indicating that even ATRA alone enhances cell-surface DR4 expression. Similarly, enhanced DR4 expression was found in SKBR3 cells exposed to the combination of TRAIL and ATRA in comparison to cells treated with TRAIL alone (Figure 6A).

Analysis of SKBR3 whole-cell lysates by western blot revealed up-regulation of DR5 protein in cultures simultaneously treated with TRAIL and ATRA in comparison to cells treated with only TRAIL or ATRA (Figure 6B).

Together, these results indicate that ATRA enhances TRAIL-induced cytotoxicity, possibly by inducing DR4 and DR5 expression in breast cancer cell lines, triggering subsequent death receptor-mediated intracellular apoptosis.

\section{Discussion}

In this study, the cytotoxic potential of TRAIL and ATRA was evaluated. Initial investigations revealed that triple-negative cell lines with a mesenchymal phenotype in particular displayed high sensitivity to TRAIL, whereas cell culture models with an epithelial phenotype were commonly resistant or only moderately sensitive. These findings were consistent with a series of studies already published (5, 29-36). Concerning sensitivity of breast cancer cells to retinoids, it has been proposed that ER $\alpha$ as well as RAR $\alpha$ expressing cell lines were particularly highly sensitive. The present study shows that ER $\alpha$-positive cell lines were among the ATRA-responsive as well as the ATRA-resistant groups of breast cancer cell lines. ER $\alpha$-negative cell lines with high ATRA sensitivity were also found. Accordingly, it has been reported that the ER $\alpha$ negative SKBR3 and Hs578T cell lines were highly retinoid responsive $(8,16,17,37-41)$; these cell lines displayed high RAR $\alpha$ expression. Our experiments also revealed that a proportion of epithelial cell lines with known high RAR $\alpha$ expression were also highly ATRA responsive. Consistently, another study identified RAR $\alpha$ as the principal mediator of ATRA responsiveness in breast cancer (42). However, we also found two epithelial RAR $\alpha$-positive cell lines to be resistant to ATRA treatment. The two mesenchymal cell lines MDAMB-231 and-436 were also resistant. Taking all results into account, we hypothesize that epithelial breast cancer cell lines in particular, but not all, may be sensitive to retinoid treatment and that expression of RAR $\alpha$ may be one, but not the sole, predictive marker for retinoid sensitivity.

Retinoids are known for their potential in cancer prevention and induction of differentiation processes as well as for antiproliferative and pro-apoptotic pathways in already transformed cells (43). Our results showed that a relevant growth-inhibitory effect in breast cancer cells requires an ATRA concentration of 0.1 to $0.5 \mu \mathrm{mol} / 1$ for moderately sensitive cell lines and concentrations in the micromolar range for rather resistant cell lines (Table II, Figures 1 and $2)$. Other studies also stated concentrations in at least the micromolar range $(17,44-47)$. Plasma retinoid concentrations measured for the maximum tolerated doses in clinical studies ranged from $0.6 \mu \mathrm{M}$ to $47 \mu \mathrm{M}$ depending on whether administration was oral or intravenous (48-52).

Notably, we observed a relevant reduction of IC50 values for a subset of epithelial breast cancer cell lines after combining ATRA with TRAIL. Taken together, our data indicate a mutual enhancement of growth-inhibiting effects. Therefore, we conclude that the doses of TRAIL and ATRA when administered in combination may be reduced and that this may lead to a lower level of systemic toxicity compared to the respective single-agent application.

Death receptors are known to be broadly expressed in malignancies and non-transformed tissues (53). However, it has been shown that death receptor up-regulation as well as application of TRAIL in combination with chemotherapeutics resulted in a sensitization of non-transformed cells toward ligand-induced apoptosis $(54,55)$. With regard to systemic 
toxicity, we evaluated growth-inhibitory effects of TRAIL, ATRA and their combination on MCF-10A cell cultures and observed an at best low responsiveness to TRAIL and resistance to ATRA. IC $_{50}$ values were not reached for TRAIL doses up to $320 \mathrm{ng} / \mu \mathrm{l}$ and for ATRA doses up to $3.2 \mu \mathrm{mol} / 1$ (data not shown). This is in accordance with findings of Sun et al.: whereas a combination of TRAIL and the synthetic retinoid CD437 induced apoptosis of non-small cell lung cancer cells, it had no cytotoxic effect on normal pulmonary epithelial cells (20). Therefore, we assume a low susceptibility of normal tissues to the effects of TRAIL and ATRA combination.

As TRAIL is known to induce apoptosis and ATRA is described as a differentiation-inducing agent, we expected cytotoxic as well as cytostatic effects of their combination (11-14). Indeed, clonogenic assay revealed smaller and also fewer colonies of SKBR3 and MCF-7 cells (Figure 3). Moreover, the the fraction of sub- $\mathrm{G}_{1}$ phase cells and amount of DNA fragmentation were increased in SKBR3 cells treated with TRAIL and ATRA (Figure 4). These findings indicate the disintegration of nucleic acids and nuclear membrane structures, which is highly suggestive of apoptosis induction.

Combinatory effects of TRAIL and retinoids have already been elucidated for diverse tumor entities: the synthetic retinoid CD437 in non-small cell lung cancer and prostate cancer cells, and the semisynthetic retinoid 4HPR in ovarian cancer and Ewing sarcoma cultures increased TRAILinduced apoptosis $(22,25)$. Taken together with the results of this study, we consider this combination to be comprehensively applicable.

Mechanisms underlying TRAIL resistance comprise, among others, under-representation of pro-apoptotic and over-representation of anti-apoptotic BCL2 family proteins, up-regulation of inhibitors of apoptosis proteins and downregulation of death receptors. In vitro studies have already shown re-sensitization of tumor cells to TRAIL-induced apoptosis by down-regulation of anti-apoptotic BCL2 family members and inhibitors of apoptosis, by up-regulation of pro-apoptotic BCL2 family proteins, as well as by augmentation of DR4 and DR5 expression. Knockdown of pro-apoptotic BAX and BAK protein in murine embryonal fibroblasts, for instance, led to inhibition of TRAIL-induced cytochrome c release (55). Correspondingly, expression of anti-apoptotic MCL1 has been correlated with tumor cell resistance to TRAIL, whereas MCL1 knockdown has been shown to be associated with resensitization (56). Amm et al. stated that the synergistic cytotoxicity of a death receptor antibody combined with doxorubicin or bortezomib was due to down-regulation of pro-apoptotic and up-regulation of anti-apoptotic BCL2 family proteins in T47D and BT-474 breast cancer cells (36). Western blot analysis showed TRAIL combined with ATRA down-regulated BCL2 and

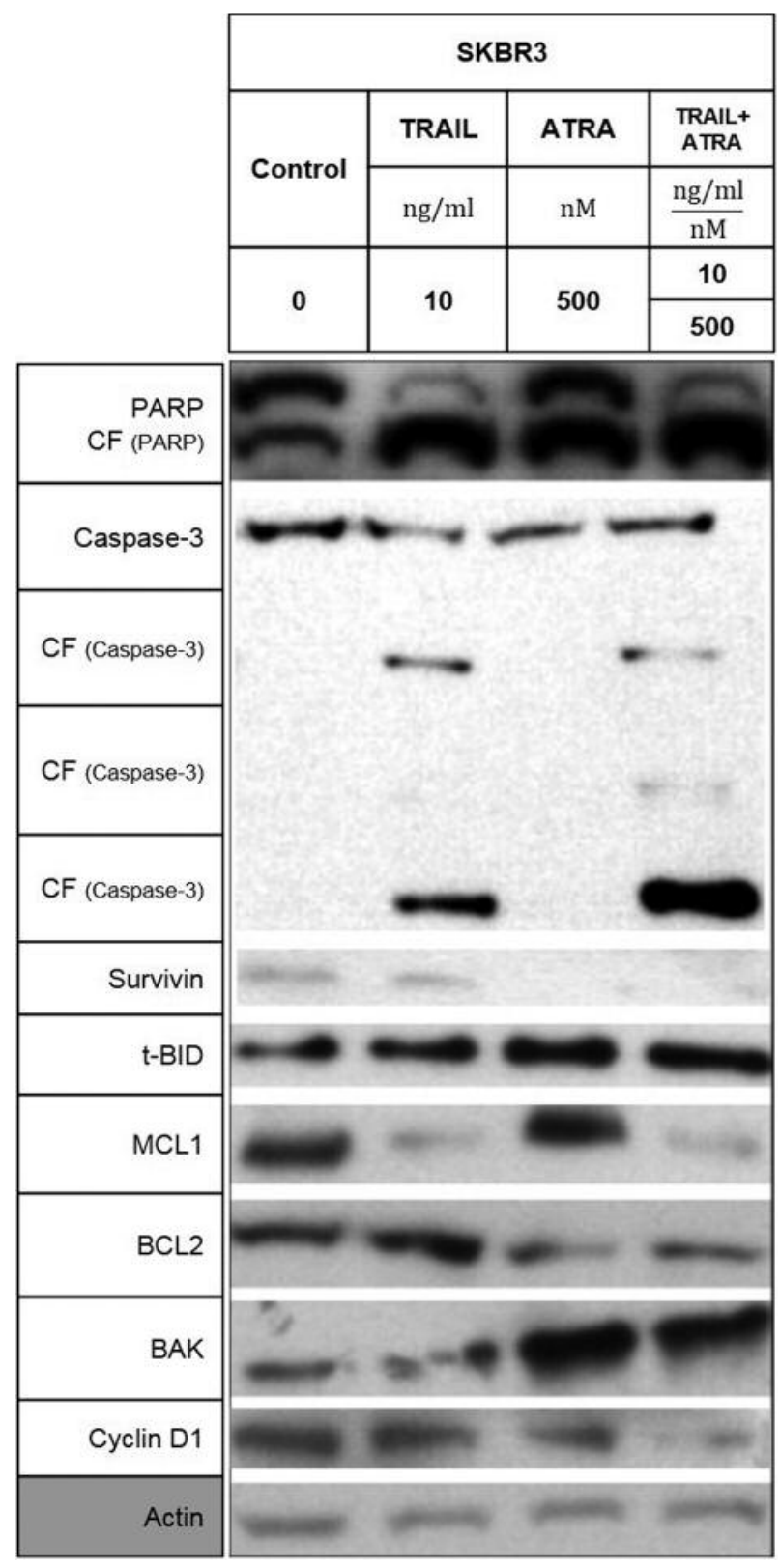

Figure 5. Differential expression of protein components taking part in signal transduction pathways related to apoptosis and cell survival dependent on treatment with TRAIL, ATRA or their combination in SKBR3 cells. SKBR3 cells were seeded in $10 \mathrm{~cm}$ diameter petri dishes and incubated with the indicated concentrations of agents for $24 \mathrm{~h}$. Different apoptosis-regulating proteins were detected in whole-cell protein lysates via western blot. Actin expression served as a loading control. Samples were derived from the same experiment. Gels and blots were processed in parallel. CF: cleaved fragment, BAK: BCL2 homologous antagonist/killer, $t$-BID: truncated BH3-interacting domain death agonist, MCL1: myeloid cell leukemia 1, BCL2: B-cell lymphoma 2, PARP: Poly ADP-ribose polymerase 1, TRAIL: tumor necrosis factorrelated apoptosis-inducing ligand, ATRA: trans retinoic acid. 
A

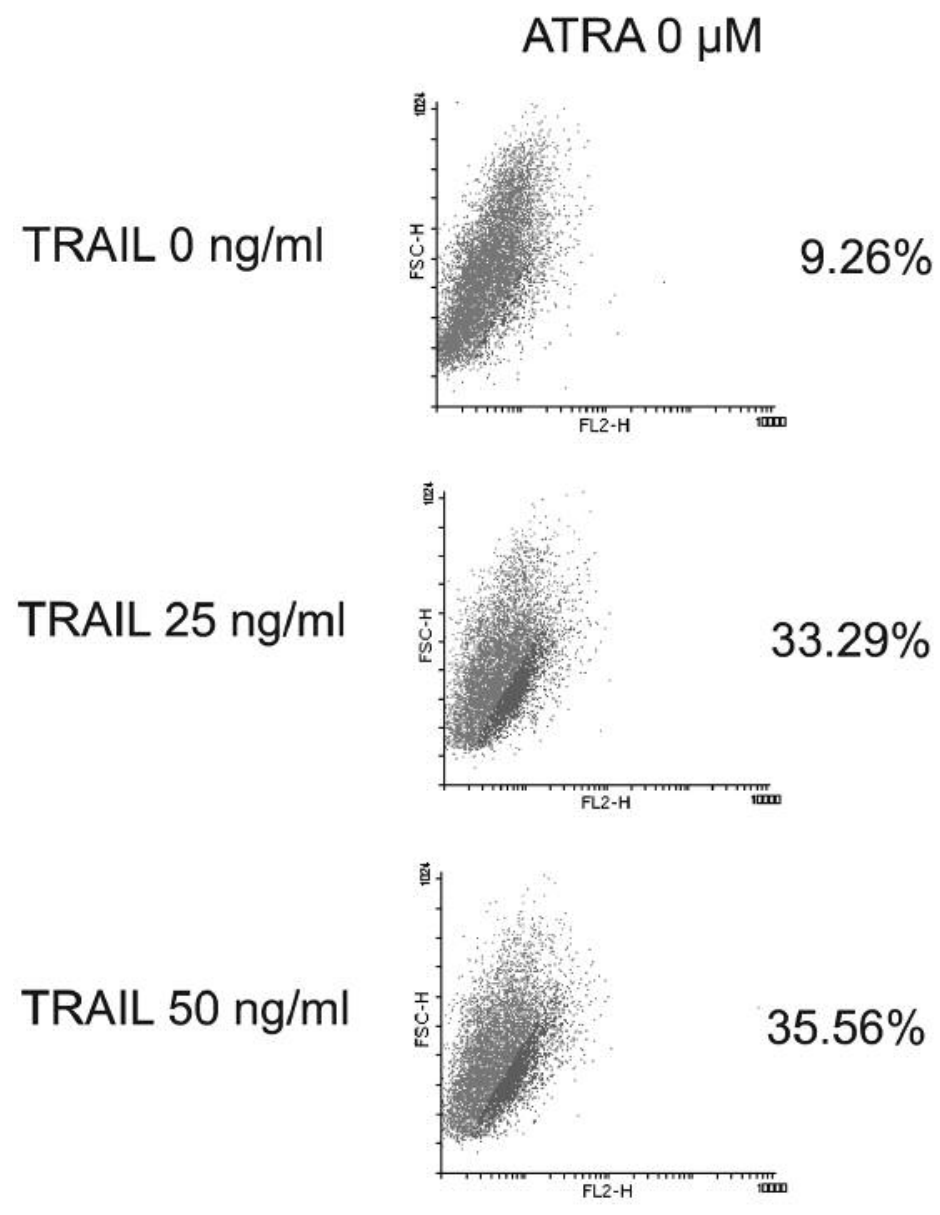

SKBR3
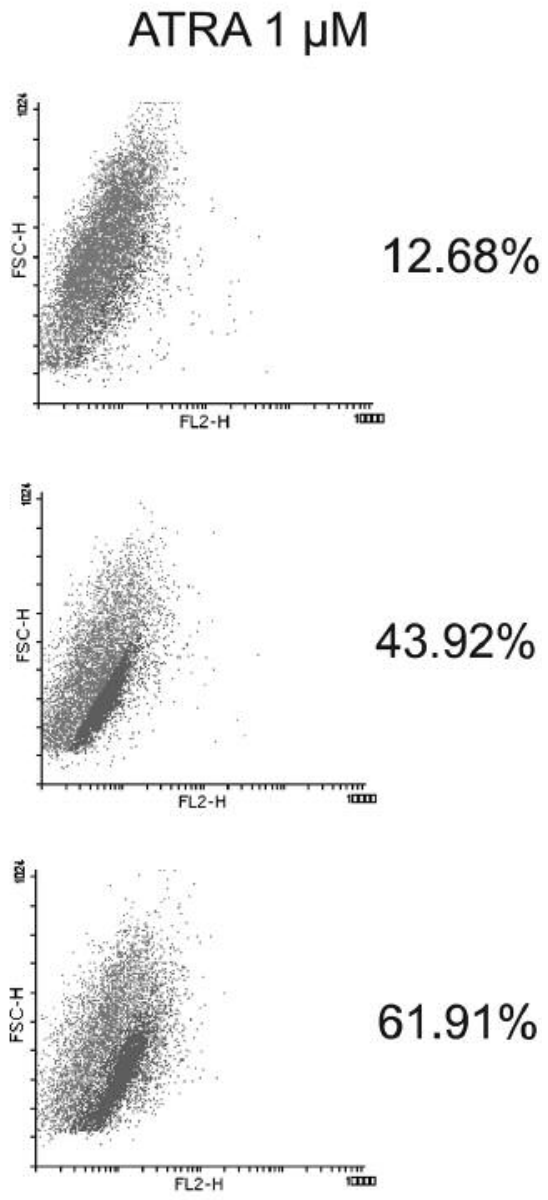

B

\begin{tabular}{|c|c|c|c|c|c|c|}
\hline \multicolumn{7}{|c|}{ SKBR3 } \\
\hline \multirow{2}{*}{$\begin{array}{l}\overline{0} \\
\text { 호 } \\
\text { o }\end{array}$} & \multicolumn{2}{|c|}{ TRAIL } & \multicolumn{2}{|c|}{ ATRA } & \multicolumn{2}{|c|}{ TRAIL+ATRA } \\
\hline & \multicolumn{2}{|c|}{$\mathrm{ng} / \mathrm{ml}$} & \multicolumn{2}{|c|}{$\mathrm{nM}$} & \multicolumn{2}{|c|}{$\frac{\mathrm{ng} / \mathrm{ml}}{\mathrm{nM}}$} \\
\hline \multirow{2}{*}{0} & \multirow{2}{*}{2.5} & \multirow{2}{*}{10} & \multirow{2}{*}{25} & \multirow{2}{*}{100} & 2.5 & 10 \\
\hline & & & & & 25 & 100 \\
\hline
\end{tabular}
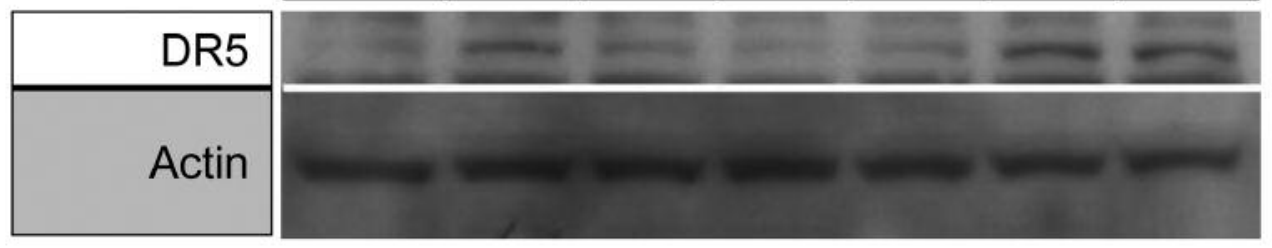

Figure 6. ATRA augments the expression of DR4 and DR5 in SKBR3 cells. A: SKBR3 cells were treated with TRAIL (25 $\mathrm{ng} / \mathrm{ml}, 50 \mathrm{ng} / \mathrm{ml})$, ATRA (1 $\mu \mathrm{M})$, or the combination of TRAIL and ATRA for $48 \mathrm{~h}$. Cells were then stained with phycoerythrin-conjugated anti-DR4 for 30 min and DR4 expression was measured by flow cytometry. B: SKBR3 cells were seeded in $10 \mathrm{~cm}$ diameter petri dishes and incubated with indicated concentrations of agents for 4 days. DR5 was detected in whole-cell protein lysates via western blot. Actin expression served as loading control. DR4: TRAIL receptor 1, DR5: TRAIL receptor 2, TRAIL: tumor necrosis factor-related apoptosis-inducing ligand, ATRA: trans retinoic acid. 
MCL1, and up-regulated BAK and t-BID, which strongly suggests BCL2 family members to be one component of the mechanism underlying TRAIL resistance in breast cancer cells. As shown by our study, regulation of these proteins by ATRA might possibly contribute to overcoming TRAIL resistance in SKBR3 cells. Our data therefore reinforce the known role of BCL2 family proteins in the framework of TRAIL- and ATRA-induced cytotoxicity.

Inhibitors of apoptosis limit effector caspase activity and procaspase- 9 cleavage. Consequently, their expression correlates with resistance to TRAIL-induced apoptosis (5557). Down-regulation of survivin in ATRA-treated SKBR3 cell cultures (Figure 5) suggests its involvement in the reduction of cell viability observed in TRAIL- and ATRAtreated SKBR3 cells. Furthermore, down-regulation of cyclin D1 expression was detected in SKBR3 cells treated with this combination. Since overexpression of cyclin D was reported to correlate with radiation resistance and chemoresistance in HER2-overexpressing breast carcinoma, possibly by inhibiting apoptosis, we consider this cell-cycle regulator also to be involved in resistance to TRAIL (58).

The relevance of DR4 for breast cancer cell survival has already been stated, as DR4 overexpression resulted in clear viability reduction in five out of six breast cancer cell lines (54). Besides, it has been demonstrated that ATRA increased DR4 levels at the transcriptional level. Furthermore, two putative RAREs in the 5'-flanking region of $D R 4$ gene were identified, which led to the speculation that DR4 might be an RAR target gene (58). This study revealed up-regulation of DR4 on the cell membrane surface of SKBR3 cells treated with ATRA alone and a further enhancement of DR4 expression when TRAIL and ATRA were simultaneously applied (Figure 6A). In addition, DR5 protein expression increased in SKBR3 cultures treated with both TRAIL and ATRA (Figure 6B). DR5 has been shown to play an important role in TRAIL-induced apoptosis of breast cancer cells (16, 59). Pan et al. also demonstrated its relevance, as they found MCF-7 cells become apoptotic after DR5 overexpression (60). Hence, we consider DR5 to be a relevant component in TRAIL-induced apoptosis of breast cancer cells. We assume that the combinatory effect of TRAIL and ATRA may at least in part result from DR5 up-regulation.

\section{Conclusion}

This study revealed that the combination of TRAIL and ATRA was more potent than each single drug alone in reducing cell viability in a subgroup of epithelial breast cancer in vitro models. These effects were attributed to cytostatic and cytotoxic mechanisms. Intensified apoptosis induction after combination treatment was one of the underlying mechanisms. Given that TRAIL triggers extrinsic and subsequently intrinsic pro-apoptotic signaling pathways by binding to its cell surface receptors DR4 and DR5, increased DR4 and DR5 expression after ATRA treatment, as demonstrated by our data, may be responsible for the more potent apoptosis-inducing effect of the TRAIL and ATRA combination treatment. Our study suggests that integration of ATRA in treatment regimens based on TRAIL or possibly TRAIL receptor agonists will contribute to overcoming TRAIL resistance in breast cancer.

\section{Acknowledgements}

All experimental procedures applied in this study were conducted in accordance with the Helsinki Declaration of 1975.

The Authors are very grateful to Dr. Anja Müller, Department of Hematology and Oncology, Vivantes Klinik am Urban, Berlin, Germany, for kindly providing the antibodies to DR4 and DR5, as well as for the technical support for cytometric analysis.

\section{Funding}

This study was supported by Berliner Krebsgesellschaft e.V. and Universitäre Forschungsförderung, Charité.

\section{References}

1 Gonzalez-Angulo AM, Morales-Vasquez F and Hortobagyi GN: Overview of resistance to systemic therapy in patients with breast cancer. Adv Exp Med Biol 608: 1-22, 2007.

2 Newsom-Davis T, Prieske S and Walczak H: Is TRAIL the holy grail of cancer therapy? Apoptosis 14: 607-623, 2009.

3 Rahman M, Pumphrey JG and Lipkowitz S: The TRAIL to targeted therapy of breast cancer. Adv Cancer Res 103: 43-73, 2009.

4 Singh TR, Shankar S, Chen X, Asim M and Srivastava RK: Synergistic interactions of chemotherapeutic drugs and tumor necrosis factor-related apoptosis-inducing ligand/Apo-2 ligand on apoptosis and on regression of breast carcinoma in vivo. Cancer Res 63: 5390-5400, 2003.

5 Rahman M, Davis SR, Pumphrey JG, Bao J, Nau MM, Meltzer PS and Lipkowitz S: TRAIL induces apoptosis in triple-negative breast cancer cells with a mesenchymal phenotype. Breast Cancer Res Treat 113: 217-230, 2009.

6 Finn RS, Dering J, Ginther C, Wilson CA, Glaspy P, Tchekmedyian N and Slamon DJ: Dasatinib, an orally active small molecule inhibitor of both the src and abl kinases, selectively inhibits growth of basal-type/"triple-negative" breast cancer cell lines growing in vitro. Breast Cancer Res Treat 105: 319-326, 2007.

7 Poulain S, Evenou F, Carre MC, Corbel S, Vignaud JM and Martinet N: Vitamin A/retinoids signalling in the human lung. Lung Cancer 66: 1-7, 2009.

8 Liu Y, Lee MO, Wang HG, Li Y, Hashimoto Y, Klaus M, Reed JC and Zhang $\mathrm{X}$ : Retinoic acid receptor beta mediates the growthinhibitory effect of retinoic acid by promoting apoptosis in human breast cancer cells. Mol Cell Biol 16: 1138-1149, 1996.

9 Michalik L and Wahli W: Guiding ligands to nuclear receptors. Cell 129: 649-651, 2007.

10 Noy N: Between death and survival: retinoic acid in regulation of apoptosis. Annu Rev Nutr 30: 201-217, 2010. 
11 Altucci L, Rossin A, Raffelsberger W, Reitmair A, Chomienne $\mathrm{C}$ and Gronemeyer $\mathrm{H}$ : Retinoic acid-induced apoptosis in leukemia cells is mediated by paracrine action of tumor-selective death ligand TRAIL. Nat Med 7: 680-686, 2001.

12 Altucci $\mathrm{L}$ and Gronemeyer $\mathrm{H}$ : The promise of retinoids to fight against cancer. Nat Rev Cancer 1: 181-193, 2001.

13 Veronesi U, De Palo G, Marubini E, Costa A, Formelli F, Mariani L, Decensi A, Camerini T, Del Turco MR, Di Mauro MG, Muraca MG, Del Vecchio M, Pinto C, D'Aiuto G, Boni C, Campa T, Magni A, Miceli R, Perloff M, Malone WF and Sporn MB: Randomized trial of fenretinide to prevent second breast malignancy in women with early breast cancer. J Natl Cancer Inst 91: 1847-1856, 1999.

14 Veronesi U, Mariani L, Decensi A, Formelli F, Camerini T, Miceli R, Di Mauro MG, Costa A, Marubini E, Sporn MB and De Palo G: Fifteen-year results of a randomized phase III trial of fenretinide to prevent second breast cancer. Ann Oncol 17: 1065-1071, 2006.

15 Gronemeyer H, Gustafsson JA and Laudet V: Principles for modulation of the nuclear receptor superfamily. Nat Rev Drug Discov 3: 950-964, 2004.

16 Sheikh MS, Shao ZM, Li XS, Dawson M, Jetten AM, Wu S, Conley BA, Garcia M, Rochefort H and Fontana JA: Retinoid-resistant estrogen receptor-negative human breast carcinoma cells transfected with retinoic acid receptor-alpha acquire sensitivity to growth inhibition by retinoids. J Biol Chem 269: 21440-21447, 1994.

17 Koay DC, Zerillo C, Narayan M, Harris LN and DiGiovanna MP: Anti-tumor effects of retinoids combined with trastuzumab or tamoxifen in breast cancer cells: induction of apoptosis by retinoid/trastuzumab combinations. Breast Cancer Res 12: R62, 2010

18 Elrod HA and Sun SY: Modulation of death receptors by cancer therapeutic agents. Cancer Biol Ther 7: 163-173, 2008.

19 Sun SY: Chemopreventive agent-induced modulation of death receptors. Apoptosis 10: 1203-1210, 2005.

20 Sun SY, Yue P, Hong WK and Lotan R: Augmentation of tumor necrosis factor-related apoptosis-inducing ligand (TRAIL)induced apoptosis by the synthetic retinoid 6-[3-(1-adamantyl)4-hydroxyphenyl]-2-naphthalene carboxylic acid (CD437) through up-regulation of TRAIL receptors in human lung cancer cells. Cancer Res 60: 7149-7155, 2000.

21 Lin YD, Chen S, Yue P, Zou W, Benbrook DM, Liu S, Le TC, Berlin KD, Khuri FR and Sun SY: CAAT/enhancer binding protein homologous protein-dependent death receptor 5 induction is a major component of SHetA2-induced apoptosis in lung cancer cells. Cancer Res 68: 5335-5344, 2008.

22 Cuello M, Coats AO, Darko I, Ettenberg SA, Gardner GJ, Nau MM, Liu JR, Birrer MJ and Lipkowitz S: N-(4-hydroxyphenyl) retinamide (4HPR) enhances TRAIL-mediated apoptosis through enhancement of a mitochondrial-dependent amplification loop in ovarian cancer cell lines. Cell Death Differ 11: 527-541, 2004.

23 Liu T, Hannafon B, Gill L, Kelly W and Benbrook D: Flex-Hets differentially induce apoptosis in cancer over normal cells by directly targeting mitochondria. Mol Cancer Ther 6: 1814-1822, 2007.

24 Jin F, Liu X, Zhou Z, Yue P, Lotan R, Khuri FR, Chung LW and Sun SY: Activation of nuclear factor-kappaB contributes to induction of death receptors and apoptosis by the synthetic retinoid CD437 in DU145 human prostate cancer cells. Cancer Res 65: 6354-6363, 2005.
25 White DE and Burchill SA: Fenretinide-dependent upregulation of death receptors through ASK1 and p38alpha enhances death receptor ligand-induced cell death in Ewing's sarcoma family of tumours. Br J Cancer 103: 1380-1390, 2010.

26 Liu H, Zang C, Fenner MH, Liu D, Possinger K, Koeffler HP and Elstner E: Growth inhibition and apoptosis in human Philadelphia chromosome-positive lymphoblastic leukemia cell lines by treatment with the dual PPARalpha/gamma ligand TZD18. Blood 107: 3683-3692, 2006.

27 Liu H, Zang C, Emde A, Planas-Silva MD, Rosche M, Kuhnl A, Schulz CO, Elstner E, Possinger K and Eucker J: Anti-tumor effect of honokiol alone and in combination with other anticancer agents in breast cancer. Eur J Pharmacol 591: 43-51, 2008.

28 Chou TC and Talalay P: Quantitative analysis of dose-effect relationships: the combined effects of multiple drugs or enzyme inhibitors. Adv Enzyme Regul 22: 27-55, 1984.

29 Buchsbaum DJ, Zhou T, Grizzle WE, Oliver PG, Hammond CJ, Zhang S, Carpenter $\mathrm{M}$ and LoBuglio AF: Antitumor efficacy of TRA-8 anti-DR5 monoclonal antibody alone or in combination with chemotherapy and/or radiation therapy in a human breast cancer model. Clin Cancer Res 9: 3731-3741, 2003.

30 Chinnaiyan AM, Prasad U, Shankar S, Hamstra DA, Shanaiah M, Chenevert TL, Ross BD and Rehemtulla A: Combined effect of tumor necrosis factor-related apoptosis-inducing ligand and ionizing radiation in breast cancer therapy. Proc Natl Acad Sci USA 97: 1754-1759, 2000.

31 Keane MM, Ettenberg SA, Nau MM, Russell EK and Lipkowitz S: Chemotherapy augments TRAIL-induced apoptosis in breast cell lines. Cancer Res 59: 734-741, 1999.

32 Garimella SV, Rocca A and Lipkowitz S: WEE1 inhibition sensitizes basal breast cancer cells to TRAIL-induced apoptosis. Mol Cancer Res 10: 75-85, 2012.

33 Oliver PG, LoBuglio AF, Zhou T, Forero A, Kim H, Zinn KR, Zhai G, Li Y, Lee CH and Buchsbaum DJ: Effect of anti-DR5 and chemotherapy on basal-like breast cancer. Breast Cancer Res Treat 133: 417-426, 2012.

34 Kazhdan I and Marciniak RA: Death receptor 4 (DR4) efficiently kills breast cancer cells irrespective of their sensitivity to tumor necrosis factor-related apoptosis-inducing ligand (TRAIL). Cancer Gene Ther 11: 691-698, 2004.

35 Zhang Y and Zhang B: TRAIL resistance of breast cancer cells is associated with constitutive endocytosis of death receptors 4 and 5. Mol Cancer Res 6: 1861-1871, 2008.

36 Amm HM, Zhou T, Steg AD, Kuo H, Li Y and Buchsbaum DJ: Mechanisms of drug sensitization to TRA-8, an agonistic death receptor 5 antibody, involve modulation of the intrinsic apoptotic pathway in human breast cancer cells. Mol Cancer Res 9: 403417, 2011.

37 Costa A: Breast cancer chemoprevention. Eur J Cancer 29A: 589-592, 1993.

38 Hansen LA, Sigman CC, Andreola F, Ross SA, Kelloff GJ and De Luca LM: Retinoids in chemoprevention and differentiation therapy. Carcinogenesis 21: 1271-1279, 2000.

39 Fitzgerald P, Teng M, Chandraratna RA, Heyman RA and Allegretto EA: Retinoic acid receptor alpha expression correlates with retinoid-induced growth inhibition of human breast cancer cells regardless of estrogen receptor status. Cancer Res 57: 26422650, 1997. 
40 Butler WB and Fontana JA: Responses to retinoic acid of tamoxifen-sensitive and -resistant sublines of human breast cancer cell line MCF-7. Cancer Res 52: 6164-6167, 1992.

41 Alsafadi S, Even C, Falet C, Goubar A, Commo F, Scott V, Quidville V, Albiges L, Dieci MV, Guegan J, Lazar V, Ahomadegbe JC, Delaloge S and Andre F: Retinoic acid receptor alpha amplifications and retinoic acid sensitivity in breast cancers. Clin Breast Cancer 13: 401-408, 2013.

42 Centritto F, Paroni G, Bolis M, Garattini SK, Kurosaki M, Barzago MM, Zanetti A, Fisher JN, Scott MF, Pattini L, Lupi M, Ubezio P, Piccotti F, Zambelli A, Rizzo P, Gianni M, Fratelli M, Terao M and Garattini E: Cellular and molecular determinants of all-trans retinoic acid sensitivity in breast cancer: Luminal phenotype and RARalpha expression. EMBO Mol Med 7: 950-972, 2015.

43 Kong G, Kim HT, Wu K, DeNardo D, Hilsenbeck SG, Xu XC, Lamph WW, Bissonnette R, Dannenberg AJ and Brown PH: The retinoid X receptor-selective retinoid, LGD1069, down-regulates cyclooxygenase- 2 expression in human breast cells through transcription factor crosstalk: implications for molecular-based chemoprevention. Cancer Res 65: 3462-3469, 2005.

44 Rubin M, Fenig E, Rosenauer A, Menendez-Botet C, Achkar C, Bentel JM, Yahalom J, Mendelsohn J and Miller WH Jr.: 9-Cis retinoic acid inhibits growth of breast cancer cells and downregulates estrogen receptor RNA and protein. Cancer Res 54: 6549-6556, 1994.

45 Bacus SS, Kiguchi K, Chin D, King CR and Huberman E: Differentiation of cultured human breast cancer cells (AU-565 and MCF-7) associated with loss of cell surface HER-2/neu antigen. Mol Carcinog 3: 350-362, 1990.

46 Tari AM, Lim SJ, Hung MC, Esteva FJ and Lopez-Berestein G: Her2/neu induces all-trans retinoic acid (ATRA) resistance in breast cancer cells. Oncogene 21: 5224-5232, 2002.

47 Offterdinger M, Schneider SM, Huber $\mathrm{H}$ and Grunt TW: Retinoids control the expression of c-erbB receptors in breast cancer cells. Biochem Biophys Res Commun 251: 907-913, 1998.

48 Miller VA, Rigas JR, Benedetti FM, Verret AL, Tong WP, Kris MG, Gill GM, Loewen GR, Truglia JA, Ulm EH and Warrell RP, Jr.: Initial clinical trial of the retinoid receptor pan agonist 9-cis retinoic acid. Clin Cancer Res 2: 471-475, 1996.

49 Ozpolat B, Lopez-Berestein G, Adamson P, Fu CJ and Williams AH: Pharmacokinetics of intravenously administered liposomal all-trans-retinoic acid (ATRA) and orally administered ATRA in healthy volunteers. J Pharm Pharm Sci 6: 292-301, 2003.

50 Estey E, Thall PF, Mehta K, Rosenblum M, Brewer T, Jr., Simmons V, Cabanillas F, Kurzrock R and Lopez-Berestein G: Alterations in tretinoin pharmacokinetics following administration of liposomal all-trans retinoic acid. Blood 87: 3650-3654, 1996.

51 Kurzrock R, Estey E and Talpaz M: All-trans retinoic acid: tolerance and biologic effects in myelodysplastic syndrome. $\mathrm{J}$ Clin Oncol 11: 1489-1495, 1993.

52 Sonnemann J, Trommer N, Becker S, Wittig S, Grauel D, Palani $\mathrm{CD}$ and Beck JF: Histone deacetylase inhibitor-mediated sensitization to TRAIL-induced apoptosis in childhood malignancies is not associated with upregulation of TRAIL receptor expression, but with potentiated caspase- 8 activation. Cancer Biol Ther 13: 417-424, 2012.

53 Armeanu S, Lauer UM, Smirnow I, Schenk M, Weiss TS, Gregor $\mathrm{M}$ and Bitzer M: Adenoviral gene transfer of tumor necrosis factor-related apoptosis-inducing ligand overcomes an impaired response of hepatoma cells but causes severe apoptosis in primary human hepatocytes. Cancer Res 63: 2369-2372, 2003.

54 Pan Y, Xu R, Peach M, Huang CP, Branstetter D, Novotny W, Herbst RS, Eckhardt SG and Holland PM: Evaluation of pharmacodynamic biomarkers in a Phase 1a trial of dulanermin (rhApo2L/TRAIL) in patients with advanced tumours. Br J Cancer 105: 1830-1838, 2011.

55 Zhang L and Fang B: Mechanisms of resistance to TRAILinduced apoptosis in cancer. Cancer Gene Ther 12: 228-237, 2005.

56 Amm HM, Oliver PG, Lee CH, Li Y and Buchsbaum DJ: Combined modality therapy with TRAIL or agonistic death receptor antibodies. Cancer Biol Ther 11: 431-449, 2011.

57 Pratt MA, Niu M and White D: Differential regulation of protein expression, growth and apoptosis by natural and synthetic retinoids. J Cell Biochem 90: 692-708, 2003.

58 Dhandapani L, Yue P, Ramalingam SS, Khuri FR and Sun SY: Retinoic acid enhances TRAIL-induced apoptosis in cancer cells by upregulating TRAIL receptor 1 expression. Cancer Res 71: 5245-5254, 2011.

59 Abdulghani J and El-Deiry WS: TRAIL receptor signaling and therapeutics. Expert Opin Ther Targets 14: 1091-1108, 2010.

60 Pan G, Ni J, Wei YF, Yu G, Gentz R and Dixit VM: An antagonist decoy receptor and a death domain-containing receptor for TRAIL. Science 277: 815-818, 1997.

61 Wu Q, Dawson MI, Zheng Y, Hobbs PD, Agadir A, Jong L, Li Y, Liu R, Lin B and Zhang XK: Inhibition of trans-retinoic acidresistant human breast cancer cell growth by retinoid $\mathrm{X}$ receptorselective retinoids. Mol Cell Biol 17: 6598-6608, 1997.

62 Zhang D, Tai LK, Wong LL, Chiu LL, Sethi SK and Koay ES: Proteomic study reveals that proteins involved in metabolic and detoxification pathways are highly expressed in HER-2/neupositive breast cancer. Mol Cell Proteomics 4: 1686-1696, 2005.

63 Sarrio D, Rodriguez-Pinilla SM, Hardisson D, Cano A, MorenoBueno $\mathrm{G}$ and Palacios J: Epithelial-mesenchymal transition in breast cancer relates to the basal-like phenotype. Cancer Res 68 : 989-997, 2008.

64 Zhao Z, Zhang ZP, Soprano DR and Soprano KJ: Effect of 9cis-retinoic acid on growth and RXR expression in human breast cancer cells. Exp Cell Res 219: 555-561, 1995.

65 van der Burg B, van der Leede BM, Kwakkenbos-Isbrucker L, Salverda S, de Laat SW and van der Saag PT: Retinoic acid resistance of estradiol-independent breast cancer cells coincides with diminished retinoic acid receptor function. Mol Cell Endocrinol 91: 149-157, 1993.

66 Roman SD, Clarke CL, Hall RE, Alexander IE and Sutherland $\mathrm{RL}$ : Expression and regulation of retinoic acid receptors in human breast cancer cells. Cancer Res 52: 2236-2242, 1992.

67 van der Leede BM, van den Brink CE and van der Saag PT: Retinoic acid receptor and retinoid $\mathrm{X}$ receptor expression in retinoic acid-resistant human tumor cell lines. Mol Carcinog 8: 112-122, 1993 